\title{
Preliminary Serological Investigation on Caprine Arthritis and Encephalitis Virus Infection in a Goat Farm from North-Eastern Romanian Region
}

\author{
Iuliana MIHAI*, Ioana Cristina CRIVEI, Cristina HORHOGEA, Gheorghe SAVUȚA, Elena VELESCU \\ Department of Public Health, Faculty of Veterinary Medicine, M.Sadoveanu Street, No. 8, Iași. \\ *corresponding author: iuliabogdan2005@yahoo.com \\ Bulletin UASVM Veterinary Medicine 75(2)/2018 \\ Print ISSN 1843-5270; Electronic ISSN 1843-5378 \\ doi:10.15835/buasvmcn-vm:2017.0061
}

\begin{abstract}
:
Caprine arthritis encephalitis is an important disease of dairy goats with a worldwide distribution. Despite the eradication programs, this disease is still prevalent and causing huge financial losses due to reduced lactation performance and culling. The aim of this study was to reveal the presence of CAEV antibodies among a goat population from the North-Eastern of Romania. During 2014-2016, a total of 295 blood samples were collected from healthy or diseased animals. The serum samples were tested for CAEV antibodies detection, using the agar gel immunodiffusion (AGID) test. Within the 295 serum samples tested by AGID technique, 31.86\% were confirmed as being positive. All positive samples came from subjects without clinical signs of disease. The results obtained in this preliminary study; show that CAEV is present in French Alpine goats breed within a farm in North-Eastern of Romania.
\end{abstract}

Keywords: AGID, CAEV, goat.

\section{Introduction}

Caprine arthritis encephalitis is caused by CAE virus (CAEV) of Lentivirus genus, belonging to Retroviridae family (Peterhans et al., 1992). This virus typically affects goats of all ages, breed and gender (Balbin, 2017) and less frequently infects sheep. Infection manifests chiefly as painful arthritis and or encephalomyelitis (De Cardona, 2016). The infection is characterized by lifelong persistence of causal agent in host monocytes and macrophages and a variable length of time between infection and induction of a serologically detectable antiviral antibody response (Turina et al., 2005).

Early symptoms of infection include swelling of joint capsule and lameness (Faez et al., 2017). Although infected animals are asymptomatic and could develop an untreatable lifelong disease syndrome, they can also transmit the virus to their baby goat through colostrum or to herd-mates by direct contact (De Cardona, 2016).

The aim of this study was to reveal the presence of CAEV antibodies among a goat population from the North-Eastern of Romania using the agar gel immunodiffusion (AGID) test.

\section{Materials and methods}

From a herd with 400 French Alpine goats the blood samples 41 were collected from 295 goats, both healthy with clinical signs of disease. A total number of 265 females and 30 males with ages between 1.5 and 4 years old were taken in this study. In order to obtain serum samples, blood was harvested from jugular vein in red cap vacutainers, centrifuged for 15 minutes at 1.500 rotations/minute, separated from the clot and stored at $-20^{\circ} \mathrm{C}$. 


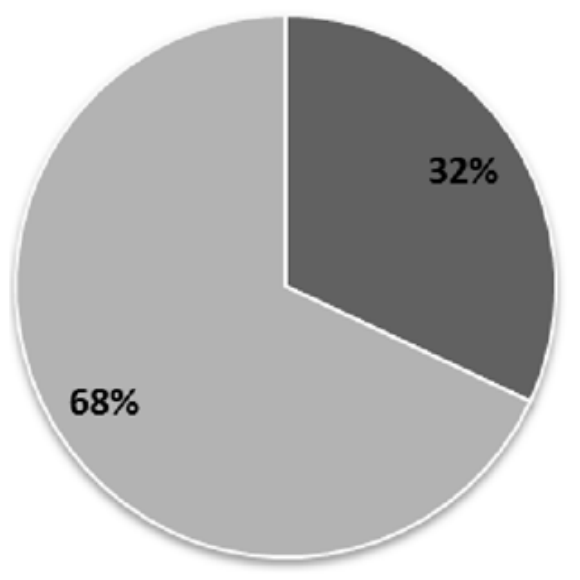

Figure 1. Prevalence of CAEV antibodies in a goat farm from North-Eastern Romanian Region

The serum samples were tested for CAEV antibodies using CAEV p28 AGID (agar gel immunodiffusion), Pourquier-Montpellier diagnostic kit. The test was performed in plastic Petri dishes, $\emptyset 10 \mathrm{~mm}$ with $17 \mathrm{ml} 1 \%$ agarose gel medium (0.05 M Tris buffer, $\mathrm{pH} 7.2$, and $8.0 \%$ $\mathrm{NaCl})$. A pattern with alternating holes was used: three large ( $5 \mathrm{~mm}$ diameter) for the serum samples $(50 \mu \mathrm{l})$, three small ( $3 \mathrm{~mm}$ diameter) for positive control test $(25 \mu \mathrm{l})$ and one central for antigen (3

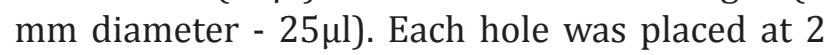
$\mathrm{mm}$ distance one by another. In each plate were tested 18 goat serum samples.

The plates were incubated at $20-24^{\circ} \mathrm{C}$ in a humid dark chamber for 24 hours, to express the precipitin lines (OIE, 2009). The positive results were retested using the same method.

\section{Results and discussions}

A total number of 295 serum samples, harvested from the same number of animals have been verified in this trial. From those, 94 were positive to CAEV antibodies, resulting a seroprevalence of $31.86 \%$ and 201 samples were negative (68.14\%) (Fig.1). Out of the 94 positive samples, only $9(9.57 \%)$ goats had clinical signs of CAEV. According to their gender, 89 (94.68\%) samples have been harvested from female goats and only 5 of them (5.32\%) from male goats. According to their age, all of the animals were younger than 3 years old.

We must add that the animals were bought from various goat breeders within different regions of Romania, or abroad (France, Switzerland, Spain and New Zeeland). Taking into consideration that a lot of the goats came from France or New Zeeland and these two countries are not CAEV free (Yang et al., 2017), our results are sustainable.

In this study, all positive samples came from goats without clinical signs of disease. Our results regarding the seroprevalence of CAEV in Romania, are supported by other studies, Enache et al., (2017) reported the $40 \%$ of CAEV seroprevalence at national level and Gurau et al., (2015) 38.46\% in only one goat flock.

However, in our study, the CAEV seroprevalence rate is close to the one in U.S.A., 31\% (Cutlip, 1992) and 35\% in Brazil (Bandeira, 2009) and lower than in Somalia (60\%) (Ghanem et al., 2009), Italy (40\%) (Gufler et al., 2007), Norway (42\%) (Nord et al., 1997) and Jordan (89\%) (Al-Qudah et al., 2006), but higher than in Mexico (0.4\%) (TorresAcosta et al., 2003), Thailand (5.52\%) (Thant et al., 2011) and Turkey (1.9\%) (Aslantas et al., 2005). Presence of CAEV infection in goat farms is alarming and is ideal to have this situation under control, considering the fact that CAEV infection is hard to manage.

Taking into consideration the seroprevalence obtained in our study, we sustain World Organization for Animal Health (OIE, 2009) recommendations for goat imports from other countries: 1 . he goats should show no clinical signs of CAEV on the day of shipment; 2 . goats over a year old should be tested negative for CAEV, 30 days prior to shipment; 3 . CAEV must be neither clinically nor serologically diagnosed at the origin of the goat flocks during the past three years, and importing goats from a flock of CAEV infected or of unknown health status are prohibited during this three year period (Yang et al., 2017). 


\section{Conclusions}

This results shows that CAEV is present in French Alpine goats within a farm in NorthEastern Romanian Region. High prevalence of CAEV (31.86\%) has been associated with low clinical signs and this confirms that CAEV infection evolves asymptomatic. We also encourage implementation of CAEV control for goats which need to be imported from other countries.

Acknowledgements. This research was partially supported by AUF (Francophone University Agency) Project: "L'optimisation des paramètres de reproduction, de génétique et de santé pour l'amélioration de la production des troupeaux de chèvres".

\section{References}

1. Al-Qudah K, Al-Majali, AM, Ismail ZB (2006). Epidemiological studies on caprine arthritis encephalitis virus infection in Jordan. Small Rum Res, 66: 181-186.

2. Aslantas O, Ozyoruk F, Gungor B (2005). Serological survey for caprine arthritis-encephalitis virus in Damascus and Kilis goats in Hatay, Turkey. Revue Med Vet, 156: 402-404.

3. Balbin MM, Mingala CN (2017). Caprine Arthritis Encephalitis, Emerging and Re-emerging Infectious Diseases of Livestock, 191-213.

4. Bandeira DA, de Castro RS, de Melo CB (2009). Seroprevalence of caprine arthritis-encephalitis virus in goats in the Cariri region, Paraiba state. Brazil Vet J Jun, 180(3):399-401.

5. Cutlip RC, Weaver ALJ (1992). Prevalence of antibody to caprine arthritis-encephalitis virus in goats in the U.S.A. Am Vet Med Assoc, 200(6):802-805.

6. De Cardona KL, PG Braun (2016). First results on small ruminant brucellosis and tuberculosis and caprine arthritis-encephalitis in El Salvador. Tropical animal health and production, 48(5):1083-1087.

7. Enache DA, Baraitareanu S, Dan M, Gurau MR, Otelea F, Dobre A, Danes D (2017). Preliminary results of MVV and CAEV seroprevalence in Romanian sheep and goats.
Scientific Works. Series C. Veterinary Medicine, LXIII (1):95-100.

8. Ghanem YM, Heybe A (2009). Prevalence and risk factors of caprine arthritis encephalitis virus infection in Northern Somalia. Small Rum Res, 85: 142-148.

9. Gufler H, Baumgartner W (2007). Overview of herd and CAEV status in dwarf goats in South Tyrol. Italy Vet $\mathrm{Q}$ 29:68-70.

10. Gurau MR, Baraitareanu S, Danes D (2015). Serological survey of caprine arthritis encephalitis virus infection in a southeastern Romanian farm. Scientific Works. Series C. Veterinary Medicine, 61(2):169-171.

11. Faez FAJ, Innocent DP, Yusuf A, Asinamai AB, Idris UH, Mohd AML, Abd WH, Wan Mswi (2017). A suspected clinical case of Caprine arthritis encephalitis (CAE) in a sheep. Int J Vet Sci Anim Husband, 2:15-17.

12. Nord K, Adnoy T (1997). Effects of infection by caprine arthritis-encephalitis virus on milk production of goats. J Dairy Sci, 80:2391-2397.

13. OIE (2009), World Animal Health Information Database Version: 1.4. World Animal Health Information Database. World Organisation for Animal Health, Paris, France. Available from: http://www.oie.int.

14. Peterhans E, Pohl B, Zanoni R, Lazary S (1992). Caprine arthritis-encephalitis, Rheumatoid arthritis, 216-230.

15. Thant NL, Saroch N, Mongkol T (2011). Seroprevalence and Risk Factors Associated with Caprine ArthritisEncephalitis Virus Infection in Goats in the Western Part of Thailand. Thai J Vet Med, 41:353-360.

16. Torres-Acosta JFJ, Gutierrez EJ, Camara GE, Lightsey J (2003). Serological survey of caprine arthritisencephalitis virus 83 goat herds of Yucatan, Mexico. Small Rum Res, 49:207-211.

17. Turina L, Pisonia G, Gianninoa ML, Moronia P (2005). Correlation between milk parameters in CAEV seropositive and negative primiparous goats during an eradication program in Italian farm. Small Rum Res, 57(1):73-79.

18. Yang WC, Chen HY, Chan KW (2017). High prevalence of caprine arthritis encephalitis virus (CAEV) in Taiwan revealed by large-scale serological survey. The Journal of Veterinary Medical Science, 79(2):273-276. 